\title{
Motivators and Outcomes of Faculty Actions towards International Students: Under the Influence of Internationalization
}

\author{
Yingxia $\mathrm{Cao}^{1}$, Xiaofan $\mathrm{Li}^{2}$, Amy Jiang ${ }^{3} \& \mathrm{Kang}_{\mathrm{Bai}}{ }^{4}$ \\ ${ }^{1}$ Assistant Professor of Decision Sciences, University of La Verne, USA \\ ${ }^{2}$ Researcher of Institutional Research, the Catholic University of America, USA \\ ${ }^{3}$ Assistant Professor of Wilson Library, University of La Verne, USA \\ ${ }^{4}$ Assistant provost for Institutional Research \& Academic Assessment, Southeast Missouri State University, USA \\ Correspondence: Yingxia Cao, Assistant Professor of Decision Sciences, University of La Verne, USA. E-mail: \\ ycao@laverne.edu
}

Received: August 13, 2014

Accepted: September 2, 2014

Online Published: September 9, 2014

doi:10.5430/ijhe.v3n4p49

URL: http://dx.doi.org/10.5430/ijhe.v3n4p49

\begin{abstract}
The population of international students continues to grow in the U.S. colleges and universities against the backdrop of internationalization, so do the studies on their academic and social experience as well as predicaments and concerns. However, most of the research has approached these issues from the perspectives of institutions and students, while little has focused on a critical player who guides and helps such experience - faculty. Hence, from the faculty's perspective, this research study analyzed quantitative responses from a questionnaire on internationalization and international students from 471 faculty members in two universities. Findings of this study revealed that a) faculty's attitudes toward internationalization and international students have significant effect on their teaching practices with international students; b) the adjustment of their teaching practices is conducive to the academic performance of international students; and c) students' enhanced learning outcomes, in turn, can raise the level of faculty satisfaction in teaching international students and their engagement in the internationalization initiative.
\end{abstract}

Keywords: Internationalization, Faculty action, International students, International education

\section{Introduction}

According to the statistics published by the Institute of International Education, there were 819,644 international students in the U.S. higher education for the 2012-2013 academic year, up 4.7 percent from the preceding year (Institute of International Education, 2012-2013). In fact, the total enrollment of international students in the U.S. has been on the steady rise throughout the past decade (The Chronicle of Higher Education, 2011-12). International students have made notable contributions to the host countries. As a lot of research indicates, international students enrich cultural diversity, academic experience, and in addition, the pipeline of students from affluent middle-class families infuses a wealth of tuition revenue to many U.S. colleges and universities.

As the influx of foreign students continues to grow in the U.S. universities and colleges, increasing attention has been paid to various issues pertinent to the difficulties and hardships that international students encounter, such as lack of adequate English proficiency and cultural alienation. Surprisingly, very little research has been published from the perspective of faculty in terms of internationalization and international students (Dewey \& Duff, 2009). Particularly, little attention has been paid to what kind of faculty actions have been undertaken to enhance the educational experience of international students, as well as why these interventions are in need and what the outcomes are. Faculty members have been the driver, leader, and implementer of internationalization (Knight, 2003), and the frontline stakeholder dealing with international students on a daily basis. In the course of delivering instruction and conducting research, faculty members have the discretion of determining the extent of international elements in their activities as well as how to deal with international students. Therefore, it is necessary to identify faculty's perceptions on internationalization and international students, as well as the incentives and disincentives associated with their decisions and actions.

This study intends to shed light on this topic by getting the input from university faculty on four questions: 1) how does faculty view internationalization, including international students? 2) What are their concerns about 
international students in terms of students' academic capacity? 3) What are the adjustments undertaken by faculty in teaching and advising to tackle these concerns? 4) What are the outcomes of these actions in terms of student learning? Using Structural Equation Modeling (SEM), a statistical technique that tests causal relations, the authors analyzed the data drawn from the results of an empirical study that gleans the input of 471 faculty members toward the internationalization agenda in general and also toward teaching and interacting with international students. It identifies the measures that faculty carried out as a result of their concerns to adjust their teaching styles in order to enhance the educational experience of international students. More importantly, the data demonstrated that faculty's perceptions toward internationalization have a significant effect on the way that they teach international students, and faculty's actions tend to bring about enhanced student learning outcomes, which in turn, affects faculty satisfaction with their engagement in internationalization and teaching international students.

\section{Literature Review}

\subsection{Internationalization and International Students}

Globalization creates abundant new opportunities for universities. Thus, as a kind of reaction to the impact of globalization (Knight, 2004), internationalization has remained high on the strategic priorities in almost half of colleges in the U.S. (The Chronicle of Higher Education, 2011-12, pp.55; Green \& Olson, 2003; Kehm, \& Teichler, 2007). Internationalization of higher education was defined as "the process of integrating an international, intercultural, or global dimension into the purpose, functions, or delivery of postsecondary education" (Knight, 2004, p.5). Internationalization in higher education includes cross-border mobility of students, faculty, staff, and educational delivery and services (Van Vught, et al., 2002). Institutions aspire to engage in internationalization with a variety of motivations: transnational academic collaboration, racial/ethnic diversity, multicultural knowledge, and so on (Altbach \& Knight, 2007; Kreber, 2009). They help American students broaden their scope and understanding of other cultures (Pearce, 2013). Moreover, economic recession and budget cuts in recent years have driven more and more higher education institutions in the U.S. to seek inflow of financial resources from overseas. According to U.S. Department of Commerce, International students contribute \$24.7 billion to the U.S. economy, through their expenditures on tuition and living expenses.

As a major component of internationalization (Kehm, \& Teichler, 2007), international students have made valuable contributions to the institutions both in their home and host countries. A large host of studies show that this mobility of students represents enrichment of resources in academics, culture, and finance to the host countries. Nonetheless, international students' adjustment in the U.S. in terms of their study and life is fraught with challenges and barriers. Throughout years, numerous studies identified lack of English language proficiency as the No.1 issue among international students (Adrian-Taylor, 2007; Gebhard, 2012; Nguyen, 2013; Sawir, et al., 2012; Trice, 2003; Sherry, et al., 2010). Language difficulty is closely connected with many other problems, such as low self-esteem, academic inefficacy, segregation, cultural barriers, and so on (Sherry, et al., 2012; Trice, 2003). Given the ever increasing number of international students, it is imperative, and yet a challenge, for faculty to respond to the needs of a diverse student population (Ryan \& Carroll, 2005).

\subsection{Lack of research on faculty's perspectives}

Contemporary organizational theories pertinent to internationalization in higher education tend to be focused more on the organizational or national level than academia (Sanderson, 2008). The majority of articles about internationalization and faculty are more likely to address the issues of internationalizing curriculum or transnational research collaborations by faculty, which boils down to a focus on the perspective of institutional strategies. Trice (2003) acknowledged that very little is known about faculty members' perceptions toward international students (pp.380). In fact, as international exchange has expanded substantially in the past decade, this shortage on research in this area has not been improved (Sawir, 2011). Bearing this same implication, Kehm \& Teichler (2007) summarized all publications on internationalization in higher education since 1990s and categorized them into three major dimensions: 1) students; 2) organization/administration; 3) macro political, economic, cultural perspective. There has been a lack of research on faculty perceptions toward internationalization and international students.

For example, in the flagship publications on international education, the Journal of Studies in International Education, only five articles that have been published since 2000 are related to faculty or academic staff on their perceptions and experiences with international students. Even in those articles about faculty and their engagement in internationalization, the major theme is likely to be written about either cross-border research collaborations or faculty's role in integrating international knowledge in curriculum and teaching. 


\subsection{The importance of faculty engagement}

Faculty plays an essential role in reinforcing institutional competence in the internationalization efforts. Nonetheless, Stohl (2007) indicated that it has been a challenge to engage faculty in the process of institutional internationalization in terms of international collaboration or services. Few faculty members acknowledged that little international ingredient was incorporated in their teaching and research other than participation in international conferences (Stohl, 2007). Childress (2010) further discussed the challenges that hinder faculty engagement in internationalization. She proposed a model called The Five I's of Faculty Engagement in Internationalization, which consists of five elements: intentionality, investment, infrastructure, institutional network, and individual support. It is not an easy task to encourage faculty's interest and commitment to internationalization (Stohl, 2007), but the increasing relevance of international dimension in the context of globalization will continue to call for the efforts of internationalization in higher education (Kreber, 2009), which inevitably involves the activities and responsibilities of faculty.

However, faculty alone might not be able to create success in the process of institutional internationalization. A case study conducted by Dewey and Duff (2009) argued that the faculty-driven approach to defining and promoting internationalization should be supported by institutional administration. In other words, to succeed as an institution-wide strategic goal, internationalization should be implemented through a top-down mechanism: centralized leadership mobilize resources and provide overarching assistance, and faculty members are responsible for specific initiatives and programs.

\section{Research Hypothesis Development}

\subsection{Faculty actions towards international students}

Many studies suggest that faculty do take actions to accommodate the diversity and challenges of international students in their teaching. For example, Sawir (2011) argued that teaching international students entails a global mindset, which is beyond specific teaching techniques. (Carroll \& Ryan, 2005) supported actions around English, writing, curriculum, supervision, and faculty-student as well as student-student interactions. In their working report to the American Council on Education on internationalization, Green \& Olson (2003) mentioned that faculty engagement in internationalization includes "working closely with international students to improve their language skills" (pp.69). McLean and Ransom (2005) offered a series of practical suggestions for "culturally aware teaching", aiming at helping students develop the academic skills necessary for their adjustment in the midst of cultural clash. The cornerstone of this way of teaching is an unbiased attitude toward international students and multicultural differences. Here are some of the recommendations (McLean and Ransom, 2005: pp.51):

1) Avoid English slangs in vocal expression;

2) Never make assumptions about what students would understand what you talk about;

3) Avoid stereotyping; not every individual conforms to the culture that this person is from;

4) Engage students to provide their input in constructing the content of a session;

5) Use gestures, signposting, and key visual displays to better illustrate ideas;

6) Encourage students to relate topics to their own cultures;

7) Provide explicit guidance during discussion sessions;

8) Create respectful atmosphere for both native and international students.

\subsection{Factors motivating faculty action}

\subsubsection{Faculty action and perceived importance of international education}

Knight (2003) reported that faculty members have been the drivers, leader, and implementer of internationalization. Internationalization and educating international students are considered important to higher education (Altbach \& Knight, 2007; Knight, 2003, 2004). Theories of reasoned action and planned behavior argue that people are more likely to adopt certain tools and take certain actions if they consider their actions to be important and useful (Ajzen, 1985; Madden, Ellen, \& Ajzen, 1992; Montano \& Kasprzyk, 2008). As educating international students is one of the essential aspects of the internationalization process, it is reasonable to hypothesize that if faculty members who deem internationalization and international students as important, they would be more likely to take actions to facilitate the process in educating international students by taking various actions. Therefore, Hypothesis 1 is proposed.

Hypothesis 1: Faculty perceived importance of internationalization and international students has positive effect on faculty action in educating international students. 


\subsubsection{Faculty action and assumed responsibility for international students}

Teaching students, including international students, constitutes an essential part of the responsibilities for faculty. In line with theory of reasoned actions and planned behaviors which considers people's actions as an outcome of their belief associated with social norms (Ajzen, 1985; Madden et al., 1992; Montano \& Kasprzyk, 2008), we would assume that sense of responsibility for faculty could also prompt them to take certain actions. It is reasonable to hypothesize that the faculty generally assume such responsibility and thus take actions to ensure the academic and other successes of international students. Thus, Hypothesis 2 is proposed.

Hypothesis2: Faculty assumed responsibility to internationalization and international students has positive effect on faculty action in educating international students.

\subsubsection{Perceived readiness and faculty action}

Studies show that those contingencies preventing faculty engagement in internationalization are usually institutional factors. Available resources, institutional support, and technology competency are some key conditions for the faculty to actually carry out their plans and also to ensure the success of such initiative (Hagner \& Schneebeck, 2001; Roberts, 2008). Ajzen (1991) argued in his theory of planned behaviors that such perceived control and readiness may act as a motivating factor and as conceivable probability to succeed in certain tasks. Since perceived readiness of the faculty is realistic in education and pedagogical adjustments, it is reasonable to presume faculty behavioral changes in the course of educating international students. Thus, Hypothesis 3 is proposed.

Hypothesis 3: Faculty readiness in dealing with internationalization and international students has positive effect on faculty action.

\subsubsection{Faculty concerns about international students}

As faculty members directly interact with international students in their teaching, they have concerns about their language and academic skills. Such concerns about international students are said to have an influence on their teaching, which, however, has not been universally acknowledged, as in many instances, international students are expected to perform and be evaluated by the same yardstick as the native students (Ryan \& Carroll, 2005). On the other hand, seeing the curriculum unfit for international students is likely to prompt faculty to tailor their instruction (Fallon \& Brown, 1999; Trice, 2005). Therefore, faculty's perception and concerns toward international students in terms of academics should serve as a starting point in adjusting pedagogy within the context of higher education (Ryan \& Carroll, 2005). Thus, Hypothesis 4 is proposed.

Hypothesis 4: Faculty concerns of international students lead to faculty action in educating international students.

\subsection{Outcomes of Faculty Action}

\subsubsection{Faculty action and performance of international students}

Positive or negative, outcome is generally expected as a result for certain action-taken. The actions can be from many aspects. For example, faculty-interaction is said to have an effect on a variety of students outcomes and their perception on their educational experience (Endo \& Harpel, 1982). (Arbaugh, 2001)'s study found that immediacy behaviors were positive predictors of student learning and course satisfaction. In regard to educating international students, many potential actions may lead to positive outcomes. For instance, (Guidry Lacina, 2002) found that colleges and universities can increase their retention of international students by providing those students with help in adjusting to U.S. culture. Thus, Hypothesis 5 is proposed.

Hypothesis 5: Faculty action has positive effect on the performance of international students.

3.3.2 Faculty satisfaction and the performance of international students

Research suggests that student performance leads to positive faculty satisfaction. For example, in an online teaching and education setting, faculty satisfaction can be positively influenced when faculty believe that they can promote positive student outcomes (Bolliger \& Wasilik, 2009). (Hartman, Dziuban, \& Moskal, 2000) concluded that faculty satisfaction is related to student outcomes and that faculty satisfaction can be dependent in such a relationship. The relationship between performance of international students and faculty satisfaction with them and related internationalization should be similar. Thus, Hypothesis 6 is proposed.

Hypothesis 6: Student performance has positive effect on faculty satisfaction with internationalization and international students. 


\subsubsection{Faculty action and faculty satisfaction}

Psychology on the cause-and-effect chain suggests that action can ultimately lead to satisfaction (Locke, 1969). A research based on two separate longitudinal studies in a hospital setting found that that personal control significantly predicted job satisfaction as well as job performance (Greenberger, Strasser, Cummings, \& Dunham, 1989). The relationship between faculty action in educating international students and their satisfaction with teaching them and related internationalization may be similar. Thus, Hypothesis 7 is proposed.

Hypothesis 7: Faculty action has positive effect on faculty satisfaction with internationalization and international students.

\section{Research Model and Methodology}

\subsection{Research model and instrument}

A research model is established to include all the variables and hypotheses mentioned above (see Figure 1). This model incorporates motivating factors of faculty actions, a series of factor actions, as well as outcomes of these actions in educating international students. The variables in the research model were operationalized with multi-measures, based on both the aforementioned literature review and interviews with faculty members who taught international students across different disciplines. The questionnaire asked respondents to select their level of agreement with various statements for each variable, using a five point Likert-scale (such as " $1=$ strongly disagree" to " $5=$ strongly agree", " $1=$ not at all concerned" to " $5=$ extremely concerned", and " $1=1=$ never" to " $5=$ always".

The questionnaire included over 90 questions, which were organized in five sections. The five sections are:

1. Importance and satisfaction about various aspects of internationalization;

2. Experiences and reviews about teaching and advising international students;

3. Concerns regarding international students and their academic performance;

4. Actions taken in teaching and communicating with international students;

5. Demographic information of the respondent.

In addition, several open-ended questions were seeking faculty comments about internationalization of higher education and international students.

\subsection{Data collection and sampling}

On behalf of two university Institutional Research offices, one in the east coast and one in the west in the United States, the authors asked that the faculty members fill out an online survey. The survey link was sent out via email to faculty members who taught during the semester in 2011. Two rounds of follow-up reminders were sent to all the potential respondents. The surveys were open for one month.

Totally 302 part-time and 169 full-time faculty members completed the survey. The response rate in one university for was $52 \%$ and in the other was $21 \%$ (the latter has a considerable number of part-time faculty members). The overall response rate was $41.9 \%$. We evaluated potential bias in the survey, by comparing late and early respondents and found no significant differences for the eight constructs, indicating non-response bias is not an issue in this analysis. 


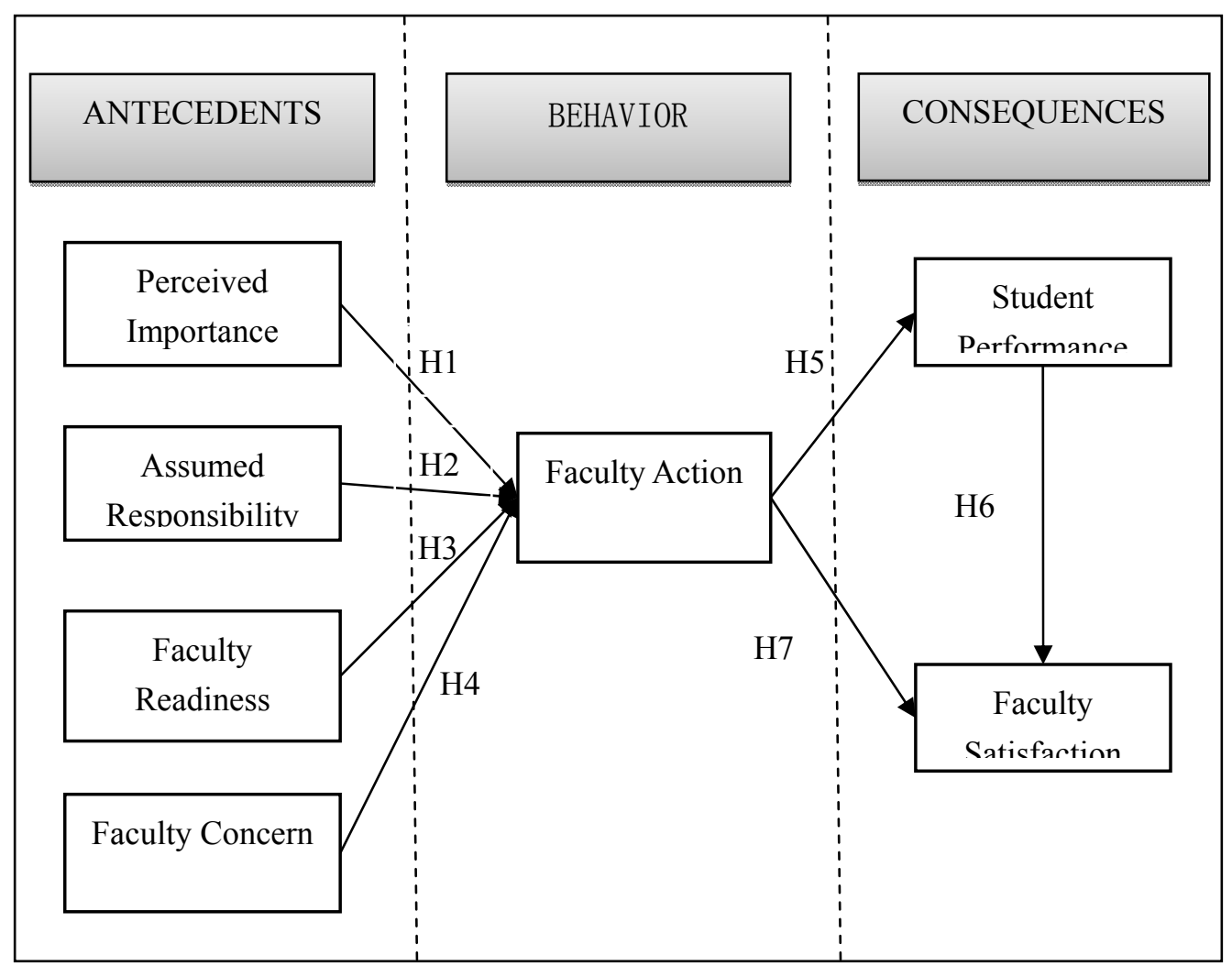

Figure 1. A Research Model of Faculty Actions for International Student Success

In this paper, only those who reported that they had taught international students are included in the data analysis because its purpose is to investigate various relationships related to faculty actions.

\subsection{Characteristics of the respondents}

Of the included respondents, the demographic information is as follows: 147 (41.6\%) were from College A and 206 (58.4\%) from College B. $72.8 \%$ of them were employed full-time at the corresponding university. In terms of gender, $55.0 \%$ were male, $38.2 \%$ were female. Regarding age, $44.5 \%$ were under $50,26.3 \%$ between 50 and 59 , and $14.4 \%$ were 60 and over. In terms of faculty appointment rank: $19.5 \%$ were full professors, $20.4 \%$ associate professors, $18.7 \%$ assistant professor, and (10.8\%) instructors, visiting professors, and lecturers, while the rest were adjunct faculty members and full-time administrators with teaching obligation. The faculty members represent a wide variety of disciplines: $42.2 \%$ from arts and sciences; 33.7\% from business and management; $14.7 \%$ from education; 5.9\% from professional colleges such as law and health sciences (Table 1). 
Table 1. Respondent Profile

\begin{tabular}{|c|c|c|c|}
\hline \multicolumn{2}{|l|}{ Demographic profile } & \multirow{2}{*}{$\begin{array}{r}N \\
147\end{array}$} & \multirow{2}{*}{$\begin{array}{r}\% \\
41.6 \%\end{array}$} \\
\hline University & A & & \\
\hline & B & 206 & $58.4 \%$ \\
\hline \multirow[t]{3}{*}{ Gender } & Male & 194 & $55.0 \%$ \\
\hline & Female & 135 & $38.2 \%$ \\
\hline & Unknown Gender & 24 & $6.8 \%$ \\
\hline \multirow[t]{5}{*}{ Age } & 39 and Younger & 77 & $21.8 \%$ \\
\hline & $40-49$ & 80 & $22.7 \%$ \\
\hline & $50-59$ & 93 & $26.3 \%$ \\
\hline & 60 and Over & 51 & $14.4 \%$ \\
\hline & Unknown Age & 52 & $14.7 \%$ \\
\hline \multirow[t]{2}{*}{ Employment Status } & Full Time & 257 & $72.8 \%$ \\
\hline & Part Time & 96 & $27.2 \%$ \\
\hline \multirow[t]{5}{*}{ Faculty Rank } & Full Professor & 69 & $19.5 \%$ \\
\hline & Associate Professor & 72 & $20.4 \%$ \\
\hline & Assistant Professor & 66 & $18.7 \%$ \\
\hline & Lectures/Instructors & 38 & $10.8 \%$ \\
\hline & Others/Adjunct & 108 & $30.6 \%$ \\
\hline \multirow[t]{5}{*}{ Teaching College } & Arts and Sciences & 149 & $42.2 \%$ \\
\hline & Business & 119 & $33.7 \%$ \\
\hline & Education & 52 & $14.7 \%$ \\
\hline & Professional (Health and Law) & 21 & $5.9 \%$ \\
\hline & Unknown College & 12 & $3.4 \%$ \\
\hline
\end{tabular}

\section{Data Analysis and Results}

\subsection{PLS (Partial Least Square)}

The authors employed SmartPLS, one of the most commonly used software packages for Partial Least Square (PLS) analysis, to test the research hypotheses and investigate the relationships among the different variables in the faculty action model (Ringle, Wende, \& Will, 2005).A PLS is a component-based structural estimation modeling technique and its features fit the purpose of this study. Simply put, it can test the strength and direction of individual paths by statistical procedures and most useful for exploratory studies where theory is not fully developed (Ainuddin, et al., 2007; Calantone, et al., 1998).

\subsection{Measurement Model and Validation}

The authors analyzed the data and interpreted the PLS results in two steps: (1) measurement model and (2) structural model. In testing the measurement model, this study established the validity (e.g., convergent and discriminant validity) and reliability of the items. In examining convergent validity (Anderson \& Gerbing, 1988; Fornell \& Larcker, 1981; Rosenzweig, 2009), the model shows that (1) the loading for each item on the constructs are significant at 0.001 level (see Table 2); (2) the average variance extracted (AVE) are greater than 0.50 (see Table 3), and (3) composite reliability higher than 0.80 (see Table 3, the threshold is 0.70 ). The authors assessed discriminant validity by examining whether the average variance extracted (AVE) from the items of the construct is greater than the average shared variance (square of the correlations in the off-diagonals) between two constructs (Fornell and Larcker, 1981). In Table 3, the square root of AVE for each construct is presented in the diagonal and all values are evident in assessing discriminant validity. In addition, reliability is assessed by the values of Cronbach's alpha and 
composite reliability. Both of them are all above 0.80 (threshold value of 0.70 ) which indicate adequate internal consistency (Cronbach, 1951; Nunnally, 1978).

Table 2. Survey Constructs, Items, and Reference and Summary of PLS Outer Loading (OL)

\begin{tabular}{|c|c|c|c|}
\hline Constructs and Items & OL & $\begin{array}{l}\text { OL: } \\
\text { SE }\end{array}$ & $\begin{array}{l}\text { OL: } t \\
\text { Value }\end{array}$ \\
\hline \multicolumn{4}{|l|}{ Action } \\
\hline 1.Speak slowly and clearly & 0.69 & 0.06 & 12.233 \\
\hline 2.Respect silence & 0.71 & 0.04 & 17.749 \\
\hline 3.Make good use of non-verbal communication & 0.75 & 0.04 & 18.523 \\
\hline 4.Avoid putting international students in the spot and never embarrass them & 0.76 & 0.04 & 17.488 \\
\hline \multicolumn{4}{|l|}{ Importance } \\
\hline $\begin{array}{l}\text { 1.Integrating international and intercultural perspectives into the academic setting of the } \\
\text { University }\end{array}$ & 0.81 & 0.03 & 31.711 \\
\hline 2.Sending the faculty to teach and conduct research at universities abroad & 0.80 & 0.03 & 26.968 \\
\hline 3.Support of internationalization from the entire the University community & 0.87 & 0.02 & 54.007 \\
\hline 4.Giving recognition for faculty's international activities in tenure and promotion & 0.76 & 0.04 & 19.500 \\
\hline
\end{tabular}

\section{Responsibility}

1. The university should do everything possible to help international students to improve their English skills.

$0.70 \quad 0.05 \quad 14.656$

2. It is the responsibility of every faculty member of the University to help international students transition into the US educational system.

$\begin{array}{lll}0.88 & 0.02 & 39.162\end{array}$

3. It is the responsibility of every faculty member of the University to help international students overcome their language difficulties.

$0.90 \quad 0.02 \quad 54.783$

\section{Readiness}

1. I am concerned about the academic progress of the international students in my class and can do my best to help them.

$\begin{array}{lll}0.81 & 0.05 & 17.916\end{array}$

2. I am always ready and available to discuss with international students any academic concerns they may have.

$\begin{array}{lll}0.88 & 0.03 & 31.550\end{array}$

3. I am readily responsive to the needs of international students.

$\begin{array}{lll}0.92 & 0.01 & 63.842\end{array}$

\section{Concern}

1. Communication with instructors

$0.80 \quad 0.26 \quad 3.114$

2. Attitudes towards instructors

3. Discussing any academic issues with instructors

$\begin{array}{lll}0.79 & 0.20 & 3.982\end{array}$

4. Discussing any academic issues with fellow students

$\begin{array}{lll}0.82 & 0.25 & 3.272\end{array}$

5. Discussing career plans with instructors

$\begin{array}{lll}0.82 & 0.20 & 4.080\end{array}$

6. Adjustment to the amount of individual responsibility expected of a student for his or her own academic problems

$\begin{array}{lll}0.83 & 0.22 & 3.772\end{array}$

7. Level of compliance with directions/instructions in the classroom

$\begin{array}{lll}0.83 & 0.20 & 4.187\end{array}$

8. Participation in class discussions and other class activities

$\begin{array}{lll}0.72 & 0.22 & 3.25\end{array}$

9. Comfort in asking questions

$\begin{array}{lll}0.66 & 0.31 & 2.14\end{array}$

10. Familiarity with the testing procedures in the classroom

$\begin{array}{lll}0.65 & 0.29 & 2.19\end{array}$

$0.75 \quad 0.21 \quad 3.57$

\section{Satisfaction}

1. An enhanced understanding of internationalization as a goal of the University

$\begin{array}{lll}0.79 & 0.02 & 31.775\end{array}$ 
2. Integrating international and intercultural perspectives into the academic setting of the University

$\begin{array}{lll}0.83 & 0.02 & 51.944\end{array}$

3. Sending the faculty to teach and conduct research at universities abroad

$\begin{array}{lll}0.77 & 0.03 & 27.932\end{array}$

4. Encouraging faculty participation in internationalization efforts

$\begin{array}{lll}0.82 & 0.02 & 36.941\end{array}$

5. Enhancing faculty's role in the internationalization of the university

$\begin{array}{lll}0.85 & 0.02 & 39.637\end{array}$

6.Incorporation of perspectives, practice, and achievements developed in other countries into the curricula of the University

$0.79 \quad 0.03 \quad 29.406$

7. Promoting the understanding and appreciation of the languages, cultures, and histories of different countries

$\begin{array}{lll}0.82 & 0.02 & 33.412\end{array}$

8. Seeing the value of being exposed to different cultures and multiple perspectives

$\begin{array}{lll}0.81 & 0.03 & 30.748\end{array}$

9. Support of internationalization from the entire the University community

$\begin{array}{lll}0.84 & 0.02 & 40.980\end{array}$

10. Increasing the population of international students from a greater diversity of countries on all the University campuses

$\begin{array}{lll}0.72 & 0.03 & 25.625\end{array}$

11. Inviting more international faculty to teach and conduct research at the University

$\begin{array}{lll}0.74 & 0.03 & 21.864\end{array}$

12. Giving recognition for faculty's international activities in tenure and promotion

$\begin{array}{lll}0.70 & 0.04 & 18.138\end{array}$

\section{Performance}

1. The international students in my classes always work hard to meet the requirements of the courses.

$\begin{array}{lll}0.86 & 0.02 & 44.772\end{array}$

2. International students in my class are making satisfactory academic progress in spite of the academic challenges they may have.

$0.92 \quad 0.01 \quad 75.951$

3. International students are adjusting themselves well in their academic studies at the University.

$\begin{array}{lll}0.89 & 0.02 & 56.535\end{array}$

Table 3. Inter-construct correlations, discriminant, convergent validity, Model quality

\begin{tabular}{llllllll}
\hline & 1 & 2 & 3 & 4 & 5 & 6 & 7 \\
\hline 1. Action & -- & & & & & & \\
2. Concern & 0.09 & -- & & & & & \\
3. Importance & 0.32 & -0.00 & -- & & & & \\
4. Performance & 0.28 & -0.23 & 0.34 & -- & & & \\
5. Readiness & 0.29 & -0.04 & 0.31 & 0.43 & -- & & \\
6. Responsibility & 0.34 & 0.02 & 0.38 & 0.35 & 0.24 & -- & -- \\
7. Satisfaction & 0.16 & -0.08 & 0.10 & 0.30 & 0.14 & 0.23 & \\
Mean & & & & & & & \\
STD & 3.85 & 2.86 & 4.01 & 3.53 & 4.37 & 3.69 & 2.93 \\
AVE & 0.70 & 0.92 & 0.83 & 0.90 & 0.71 & 0.93 & 0.84 \\
(AVE Square Root) & 0.53 & 0.59 & 0.66 & 0.80 & 0.77 & 0.69 & 0.63 \\
Composite Reliability & 0.73 & 0.77 & 0.81 & 0.89 & 0.87 & 0.83 & 0.79 \\
Cronbachs Alpha & 0.82 & 0.94 & 0.88 & 0.92 & 0.91 & 0.87 & 0.95 \\
$\mathrm{R}^{2}$ & 0.70 & 0.93 & 0.83 & 0.87 & 0.85 & 0.78 & 0.95 \\
Q $^{2}$ & $0.20(0.19)$ & & & $0.08(0.35)$ & & & $0.10(0.09)$ \\
\hline
\end{tabular}

* The numbers in the parentheses are for the analysis in Figure 3. 


\subsection{Structural equation modeling}

The authors evaluated the structural model in the second step. We tested the research hypotheses and assessed the direction, strength and level of significance of the path coefficients estimated by SmartPLS, using a bootstrap resampling method with 500 resamples (Chin, 1998). The results of the structural model with path coefficients and their significance level are shown in Figure 2. Overall, all hypotheses, except two (H4 for faculty concern-faculty action and $\mathrm{H} 8$ for faculty action-faculty satisfaction), are supported at $\mathrm{p}<0.05$ level.

To assess the interpretative ability and quality of the model, Table 3 presents the indices for explained variability $\left(\mathrm{R}^{2}\right)$ and the $\mathrm{Q}^{2}$ test for predictive relevance (redundancy). The $\mathrm{R}^{2}$ values are 0.20 for action, .08 for performance, and 0.10 for satisfaction, which means that the model has achieved some, but modest explanation for the endogenous variables. Table 3 also shows that the range for $\mathrm{Q}^{2}$ of the endogenous constructs (i.e. action, satisfaction, and outcomes) range from 0.05 to 0.11 , all positive values and indicates some predictive relevance. As $\mathrm{Q}^{2}$ measures how well observed values are reproduced by the model and its parameter estimates (Chin, 1998) and a positive value of $\mathrm{Q}^{2}$ implies that the model has predictive relevance (Tenenhaus, et al., 2005), the results of this study (see Table 3) show that the research model has some predictive relevance .

Therefore, the structural model reveals that perceived importance, assumed responsibility, and faculty readiness have positive while faculty concern has little effect on faculty action towards educating international students; faculty action has little effect on their satisfaction with international students or internationalization, though it has positive on international student performance, which in turn, has positive effect on faculty satisfaction with international students or internationalization.

This study also found that control variables such as age, gender, employment status, years of service at the university do not significantly influence the relationship among the variables.

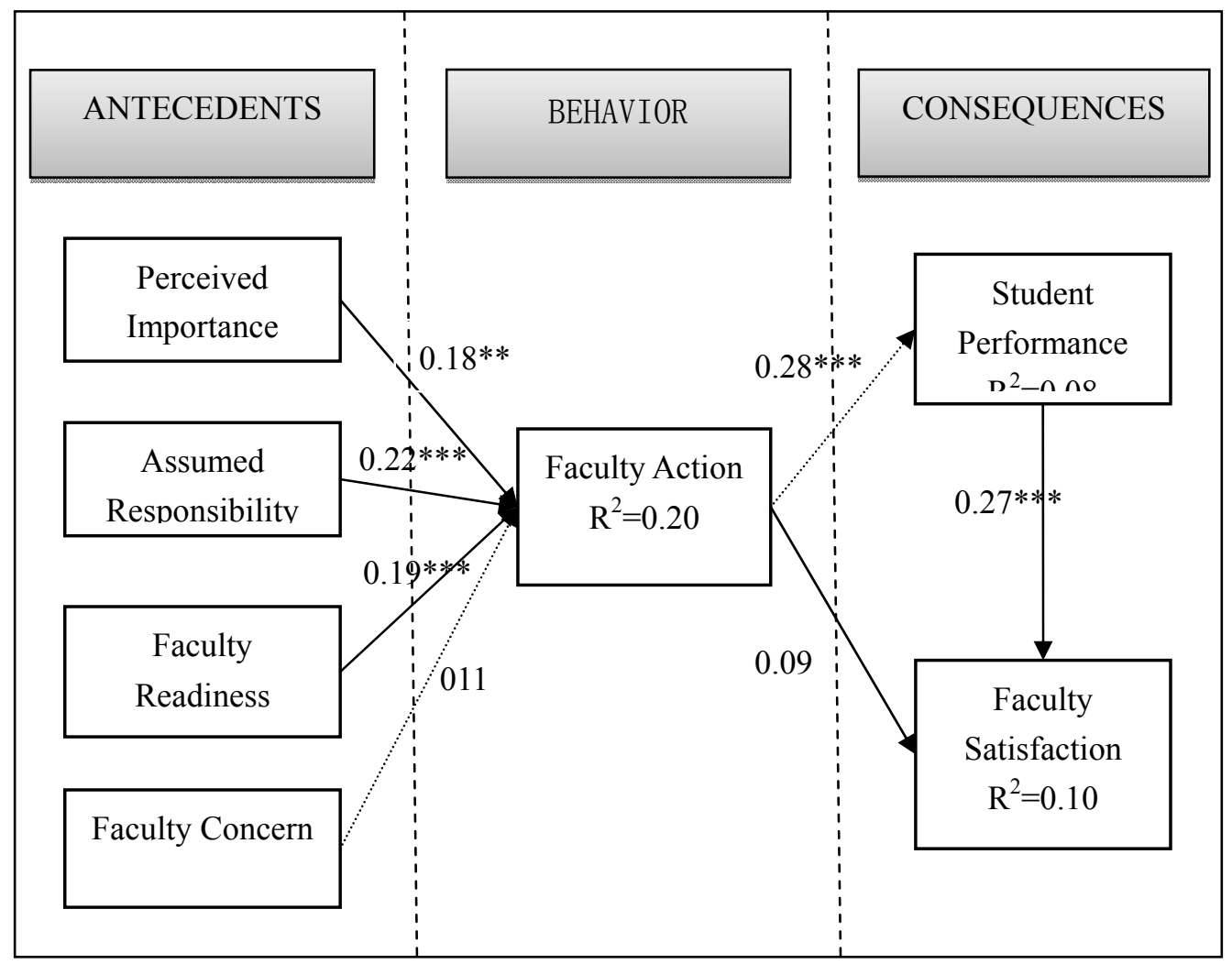

Figure 2. Faculty Actions for International Student Success

Note: $\mathrm{t}>1.96$ at $\mathrm{P}<0.05 ; \mathrm{t}>2.576$ at $\mathrm{P}<0.01 ; \mathrm{t}>3.29$ at $\mathrm{P}<0.001$ for two-tailed tests.

\section{Discussions and Conclusions}

Results from data analysis indicate that the items and constructs in the model have a satisfying degree of validity and reliability, based on the Partial Least Square test. These items and constructs constitute our research model that 
examines a number of cause-outcome relationships with intervention playing a part in between.

Commitment from faculty is the key to the success of internationalization. Consistent with the discourse by Green \& Olson (2003), our findings show that faculty members are more likely to sign up for activities geared toward internationalization, if they are proponents for this campaign. In our research study, this is one of the factors that significantly motivate professors to take actions, that is, faculty support for internationalization would lead to their willingness and ultimately actions in the course of educating and interacting with international students. In addition, this finding corroborates the psychological theory of planned action (Ajzen, 1991), where it states attitudes and beliefs will result in individual's behaviors.

Sense of responsibility, an indirect measure in the theory of planned action (Ajzen, 1991), serves as an important motivating factor in our model. This finding not only confirms a common observation, but also echoes the theory fragment where social norms and related beliefs usually prod people to take actions. Sense of responsibility should be one of the essential traits for educators. Due to the diverse needs and cultural backgrounds, international students may have a harder time achieving learning outcomes on par with their native counterparts. They may need instructors to assist their learning by providing knowledge in the context, by refraining from using colloquial discourse, by efforts of making them mingle with native students, and so on (Ryan, 2005). However, not every teacher will give special attention to international students or tailor their teaching practices to meet the needs of international students. Hence, without a doubt, if faculty put emphasis on their responsibilities in teaching international students, they are very likely to adjust or improve their way of teaching to guide these students to successful attainment of learning outcomes.

Like the other side of the same coin, readiness is another pertinent factor that motivates faculty to take actions. Similar to sense of responsibility, if faculty members feel ready to act on their beliefs, they will do so. If a teacher does not feel comfortable dealing with the distinction and difficulty caused by the multicultural aspect of a student group, he or she will more or less be nonchalant toward international students and even resistant to the idea of internationalization. This preparedness is hinged upon a variety of conditions, ranging from faculty's mindset to tangible resources readily available. Teaching approaches are inherently tied with faculty's cultural background, life experience, educational philosophy and skills in their disciplines (McLean \& Ransom, 2005). When they teach and interact with students, these intrinsic values will guide or limit their behaviors. Studies showed that faculty who were foreign born, received their education overseas, or had experience in other countries will be more likely to be proponents of internationalization (Trice, 2003). Apart from faculty's subjective emotion and cognitive competence that shape up their readiness, objective capacities at institutional 1 level also will immensely influence faculty engagement. Lack of financial resources is considered one of the salient barriers to faculty engagement in internationalization (Green \& Olson, 2003; Childress, 2010). Other barriers include disciplinary priorities, pressure of tenure, and lack of orchestrated leadership (Green \& Olson, 2003; Childress, 2010).

Contrary to what we hypothesized previously as well as what some research indicated, faculty concern about international students do not necessarily prompt them to take measures to alleviate their concern. The study indicates that faculty concern has little effect on faculty action towards educating international students. Faculty decision to take action toward educating international students has no direct relationship with their levels of concern of student skills and performance. In another word, faculty concern itself not necessarily triggers faculty action toward educating international students. In spite of their concern, other factors that we found significant, such as their sense of responsibility and/or readiness, will more likely pull the strings. If a teacher is not satisfied with the English proficiency level of the international students in her class (presumably this is not an English or ESL course), she will not necessarily do something about it if she doesn't think it is important to address this issue.

Nevertheless, faculty should be encouraged to take steps to address the issues for international students, because we found that faculty interventions could bring out beneficial outcomes in several aspects. Our findings affirm our hypotheses that faculty actions have direct and positive influence on academic and social performance of international students, and this enhanced student performance could in turn raise the level of faculty satisfaction with internationalization in higher education as well as teaching international students. 


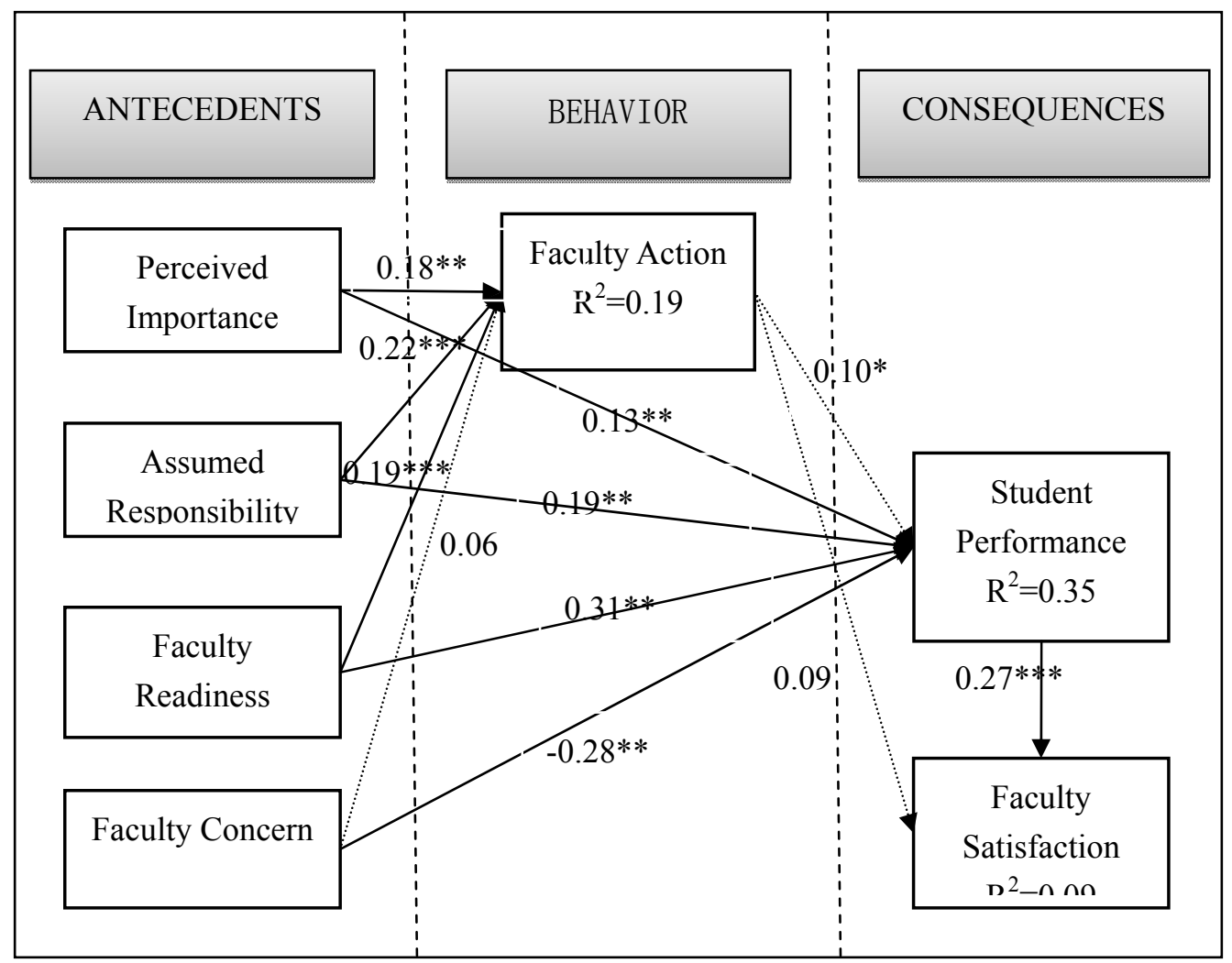

Figure 3. Faculty Actions and Other Factors Related to International Student Success

Note: $\mathrm{t}>1.96$ at $\mathrm{P}<0.05 ; \mathrm{t}>2.576$ at $\mathrm{P}<0.01 ; \mathrm{t}>3.29$ at $\mathrm{P}<0.001$ for two-tailed tests.

Furthermore, while faculty actions explain only eight percent of the variance in student performance, we found that the antecedents of faculty actions have direct relationships with student performance. As seen in Figure 4. Together with faculty action (that is not significant), the antecedents explain over $35 \%$ of the variance in international students' performance. Perceived importance, assumed responsibility, and faculty readiness have positive and faculty concern has negative effect on international student performance. The other factors have similar relationships as those shown in Figure 2.

To sum up, perceived importance of internationalization of higher education, assumed responsibility for the improvement of international students, and faculty readiness to provide help are the motivating factors for professors to take steps in the process of educating and interacting with international students. Faculty action leads to better student performance and indirectly improve their satisfaction with the internationalization of higher education, while the motivating factors are likely to have direct relationship with student performance as well.

\section{Implications, Limitations, and Directions for Future Research}

Faculty help fosters a sense of international community on campus and implement strategic objectives on university's international education agenda. Through various activities including teaching and research, faculty support schools and departments in their efforts to incorporate global perspectives into curricula, facilitate students who are engaged in international programs, and help international students achieve their learning goals on par with their native counterparts. This study has focused on the most important aspect of internationalization - faculty actions in educating international students. This focus has filled in a void in the literature. It revealed how such actions are intervened with and indirectly impact on faculty perceived importance of and experienced satisfaction with internationalization. The findings shine lights on the importance of faculty action in the internationalization process, which enriches the studies about internationalization. Scholarly, the established research model partially explains the relationship of faculty actions with other factors and it points out directions for future search.

This study also provides important practical implications for administrators. If they want to increase faculty satisfaction with internationalization and to improve the quality of international education, they should ensure that 
faculty members take actions to boost the performance of international students, which then help faculty satisfaction. They should also address the motivating factors that lead to such actions, such as perceived importance of internationalization, assumed responsibility, and faculty readiness of dealing with international students. However, faculty concerns would not make faculty to decide on take actions in educating their international students. In addition, administrators should consider the thoughts and agreement of the faculty on issues related to internationalization and international students if they want the faculty to take relevant actions.

There are several limitations of this study, which points out directions for future research. First, we did not include a comprehensive list of activities associated with faculty action. Future research could expand the activities and deepen the analysis of faculty actions. Second, this study included internationalization as major components and was mostly based on its design on literature and interview, although it adopted theory of planned behavior. Studies that expand the factors may explain faculty actions better. Additionally, future study can research and explain why faculty concerns do not lead to student performance?

In sum, this study examines and empirically tests faculty action in educating international students. Its findings strengthen literature about internationalization and international education. We hope that this study helps lay the foundation for future studies about international education from a faculty perspective, a still developing area in research. In addition, future studies should further examine how specific faculty actions lead to student performance.

\section{References}

Adrian-Taylor, S. R., Noels, K.A., \& Tischler, K. (2007). Conflict between international graduate students and faculty supervisors: Toward effective conflict prevention and management strategies. Journal of Studies in International Education, 11(1), 90-117. http://dx.doi.org/10.1177/1028315306286313

Ainuddin, R. A., Beamish, P. W., Hulland, J. S., \& Rouse, M. J. (2007). Resource attributes and firm performance in international joint ventures. Journal of World Business, 42(1), 47-60. http://dx.doi.org/10.1016/j.jwb.2006.11.001

Ajzen, I. (1985). From intentions to actions: A theory of planned behavior. Springer. Retrieved from http://link.springer.com/chapter/10.1007/978-3-642-69746-3_2

Ajzen, I. (1991). The theory of planned behavior. Organizational Behavior and Human Decision Processes, 50(2), 179-211. http://dx.doi.org/10.1016/0749-5978(91)90020-T

Altbach, P. G. \& Knight, J. (2007). The internationalization of higher education: Motivations and realities. Journal of Studies in International Education, 11(3-4), 290-305. http://dx.doi.org/10.1177/1028315307303542

Anderson, J. C., \& Gerbing, D. W. (1988). Structural equation modeling in practice: A review and recommended two-step approach. Psychological Bulletin, 103(3), 411. http://dx.doi.org/10.1037/0033-2909.103.3.411

Arbaugh, J. B. (2001). How instructor immediacy behaviors affect student satisfaction and learning in web-based courses. Business Communication Quarterly, 64(4), 42-54. http://dx.doi.org/10.1177/108056990106400405

Association of American Colleges. (1985). Integrity of the college curriculum: A report to the academic community. Washington, DC: author.

Andrade, M.S. (2009). The international student picture. In M.S. Andrade \& N.W. Evans (Eds.), International students: Strengthening a critical resource. Lanham, MD: Rowman \& Littlefield.

Bevis, B. T. \& Lucas, J. C. (2007). International students in American colleges and universities: A history. New York: Palgrave Macmillan. http://dx.doi.org/10.1057/9780230609754

Bolliger, D. U., \& Wasilik, O. (2009). Factors influencing faculty satisfaction with online teaching and learning in higher education. Distance Education, 30(1), 103-116. http://dx.doi.org/10.1080/01587910902845949

Calantone, R. J., Graham, J. L., \& Mintu-Wimsatt, A. (1998). Problem-solving approach in an international context: antecedents and outcome. International Journal of Research in Marketing, 15(1), 19-35. http://dx.doi.org/10.1016/S0167-8116(97)00028-1

Carroll, J., \& Ryan, J. (2005). Teaching International Students: Improving Learning for All. London: Routledge.

Childress, L. (2010). The twenty-first century university: Developing faculty engagement in internationalization. New York: Peter Lang.

Chin, W. W. (1998). The partial least squares approach for structural equation modeling. Retrieved from http://psycnet.apa.org/psycinfo/1998-07269-010

Choudada, R. \& Chang, L. (2012). Trends in international student mobility. World Education News \& Reviews, 25(2), 
Retrieved from: http://www.wes.org/ras/TrendsInInternationalStudentMobility.pdf

Chow, P. \& Bhandari, R. (2011). Open Doors 2011: Report on international educational exchange. New York: Institute of International Education.

Dewey, P. \& Duff, S. (2009). Reason before passion: faculty views on internationalization in higher education. Higher Education, 58, 491-504. http://dx.doi.org/10.1007/s10734-009-9207-z

Endo, J. J., \& Harpel, R. L. (1982). The effect of student-faculty interaction on students' educational outcomes. Research in Higher Education, 16(2), 115-138. http://dx.doi.org/10.1007/BF00973505 Fallon, G. \& Brown, R.B. (1999). What about the workers? Academic staff opinion about working with non-UK postgraduate students in higher education. Journal of Further and Higher Education, 23, 41-52. http://dx.doi.org/10.1007/BF00973505

Fornell, C., \& Larcker, D. F. (1981). Evaluating structural equation models with unobservable variables and measurement error. Journal of Marketing Research, 39-50. http://dx.doi.org/10.2307/3151312

Gebhard, J.G. (2012). International students' adjustment problems and behaviors. Journal of International Students, 2(2), 184-193.

Green, M.F. \& Olson, C.L. (2003). Internationalizing the campus: A user's guide. Washington, D.C.: American Council of Education.

Greenberger, D. B., Strasser, S., Cummings, L. L., \& Dunham, R. B. (1989). The impact of personal control on performance and satisfaction. Organizational Behavior and Human Decision Processes, 43(1), $29-51$. http://dx.doi.org/10.1016/0749-5978(89)90056-3

Guidry Lacina, J. (2002). Preparing international students for a successful social experience in higher education. New Directions for Higher Education, 2002(117), 21-28. http://dx.doi.org/10.1002/he.43

Hagner, P. R., \& Schneebeck, C. A. (2001). Engaging the faculty. Technology Enhanced Teaching and Learning: Leading and Supporting the Transformation on Your Campus: Jossey-Bass. Retrieved from http://media.johnwiley.com.au/product_data/excerpt/30/07879501/0787950130.pdf

Hartman, J., Dziuban, C., \& Moskal, P. (2000). Faculty satisfaction in ALNs: A dependent or independent variable. On-line Education: Learning Effectiveness and Faculty Satisfaction, 151-172.

Institute of International Education (2012-2013). Open doors 2013: International students in the United States and study abroad by American students are at all-time high. Retrieved from http://www.iie.org/Who-We-Are/News-and-Events/Press-Center/Press-releases/2013/2013-11-11-Open-DoorsData.

Kehm, \& Teichler. (2007). Research on internationalization in higher education. Journal of Studies in International Education, 11(3-4), 260-273. http://dx.doi.org/10.1177/1028315307303534

Klmegah, R. (2006). Social factors relating to alienation experienced by international students in the United States. College Student Journal, 40(2), 303-315.

Knight, J. (2003). Internationalization of higher education practices and priorities: 2003 IAU survey report. Czech Republic: UNITISK: International Association of Universities. Retrieved from http://www.pucminas.br/imagedb/documento/DOC_DSC_NOME_ARQUI20060214115459.pdf.

Knight, J. (2004). Internationalization remodeled: Definitions, approaches and rationales. Journal of Studies in International Education, 8(1), 5-31. http://dx.doi.org/10.1177/1028315303260832

Kreber, C. (2009). Different perspectives on internationalization in higher education. New Directions for Teaching and Learning, 118, 1-14. http://dx.doi.org/10.1002/t1.348

Lee, J. J. (2010). International students' experiences and attitudes at a US host institution: Self-reports and future recommendations. Journal of Research in International Education, 9, 66-84. http://dx.doi.org/10.1177/1475240909356382

Locke, E. A. (1969). What is job satisfaction? Organizational Behavior and Human Performance, 4(4), 309-336. http://dx.doi.org/10.1016/0030-5073(69)90013-0

Luo, J. \& Jamieson-Drake, D. (2013). Examining the educational benefits of interacting with international students. Journal of International Students, 3(2), 85-101. 
Madden, T. J., Ellen, P. S., \& Ajzen, I. (1992). A comparison of the theory of planned behavior and the theory of reasoned action. Personality and Social Psychology Bulletin, 18(1), 3-9. http://dx.doi.org/10.1177/0146167292181001

McCormack, (2007). Worldwide competition for international students heats up. The Chronicle of Higher Education, 54(12):A34

McLean, P. \& Ransom, L. (2005). Building intercultural competencies: Implications for academic skills development. In J. Carroll \& J. Ryan (Eds.) Teaching International Students: Improving Learning for All. London: Routlege.

Montano, D. E., \& Kasprzyk, D. (2008). Theory of reasoned action, theory of planned behavior, and the integrated behavioral model. Health Behavior and Health Education: Theory, Research, and Practice, 4, 67-95.

Nguyen, H. M. (2013). Faculty advisors' experiences with international graduate students. Journal of International Students, 3(2), 102-116.

Pearch, S. C. (2013). Enriching American riches with international students. Journal of International Students, 3(1), $1-2$.

Ringle, C. M., Wende, S., \& Will, A. (2005). SmartPLS 2.0 (M3) Beta. Hamburg, Germany: SmartPLS. Retrieved from http://www.smartpls.de/forum/bibliographic_information.php (Accessed 6/30/2014).

Roberts, C. (2008). Implementing educational technology in higher education: A strategic approach. The Journal of Educators Online, 5(1), 1-16.

Rosenzweig, E. D. (2009). A contingent view of e-collaboration and performance in manufacturing. Journal of Operations Management, 27(6), 462-478. http://dx.doi.org/10.1016/j.jom.2009.03.001

Ryan, J. \& Carroll, J. (2005). "Canaries in the coalmine": International students in Western universities. In J. Carroll \& J. Ryan (Eds.) Teaching International Students: Improving Learning for All. London: Routlege.

Ryan, J. (2005). Improving teaching and learning practices for international students: Implications for curriculum, pedagogy, and assessment. In J. Carroll \& J. Ryan (Eds.) Teaching International Students: Improving Learning for All. London: Routlege.

Sanderson, G. (2008). A foundation for the internationalization of the academic staff. Journal of Studies in International Education, 12(3), 276-307. http://dx.doi.org/10.1177/1028315307299420

Sherry, M., Thomas, P., \& Chui, W.H. (2010). International students: a vulnerable student population. Higher Education, 60, 33-46. http://dx.doi.org/10.1007/s10734-009-9284-z

Stohl, M. (2007). We have met the enemy and he is us: The role of faculty in the internationalization of higher education in the coming decade. Journal of Studies in International Education, 11(3), 359-372. http://dx.doi.org/10.1177/1028315307303923

Sawir, E. (2011). Academic staff response to international students and internationalizing the curriculum: The impact of disciplinary differences. International Journal of Academic Development, 16, 45-57. http://dx.doi.org/10.1080/1360144X.2011.546224

Sawir, E., Marginson, S., Forbes-Mewett, H., Nyland, C., and Ramia, G. (2012). International student security and English language proficiency. Journal of Studies in International Education, 16(5), 434-454. http://dx.doi.org/10.1177/1028315311435418

Tenenhaus, M., Vinzi, V. E., Chatelin, Y. M., \& Lauro, C. (2005). PLS path modeling. Computational Statistics \& Data Analysis, 48(1), 159-205. http://dx.doi.org/10.1016/j.csda.2004.03.005

The Chronicle of Higher Education. (2012). Almanac, 2011-12.

Trice, A.G. (2003). Faculty perceptions toward graduate international students: The benefits and challenges. Journal of Studies in International Education, 7(3), 379-403. http://dx.doi.org/10.1177/1028315303257120

Trice, A.G. (2005). Navigating in multinational learning community: Academic departments' responses to graduate international students. Journal of Studies in International Education, 9(1), 62-89. http://dx.doi.org/10.1177/1028315304271664

Van Vught, F., Van der Wende, M., and Westerhejden, D. (2002). Globalization and internationalization: Policy agendas compared. In J. Enders and O. Fulton (eds.), Higher Education in a Globalizing World: International Trends and Mutual Observations. A Festschrift in Honor of Ulrich Teichler, 103-121. Dordrecht, The Netherlands: Kluwer Academic Publishers. http://dx.doi.org/10.1007/978-94-010-0579-1_7 